Fredric Jameson

\title{
Post-modernismen og den sene kapitalismes kulturelle logik
}

De allerseneste år har været kendetegnet ved en slags bagvendt tusindårsrigetro, hvor forudanelser om fremtiden, katastrofiske eller indløsende, er blevet erstattet af folelsen af afslutningen på dette og hint (ideologien, kunsten, de sociale klasser; Leninismens 'krise', socialdemokratiernes, velfærdsstatens, osv., osv.). Taget under ét udgør disse symptomer måske det, som i stadig stigende grad kaldes postmodernisme.

Begrundelsen for dens eksistens hviler på en hypotese om en slags radikalt kulturelt brud, almindeligvis sat til slutningen af 1950erne eller begyndelsen af 60erne. På ét plan er dette brud naturligvis, som begrebet antyder, defineret som et brud med modernismen selv, eller høj-modernismen som jeg fremover vil kalde den. Således må den abstrakte ekspressionisme i maleriet, eksistentialismen i filosofien, de store auteur'ers film eller den akademiske kanonisering af en Wallace Stevens' poesi, - således må disse fænomener ses som det sidste enestående øjeblik for en høj-modernistisk impuls som forbruges og udtømmes ved dem. Klart nok er det jo iøvrigt i arkitekturens sfære, at disse problemer mest centralt er blevet rejst og udforsket, og det er i grunden fra arkitekturen begrebet post-modernisme stammer. Dér er fejringen af post-modernismen langt mere end kåringen af endnu en ny stil: Den indbefatter en uforsonlig kritik af det moderne selv og af den internationale stil, hvis fallit er udtalt på det bymæssige niveau, hvor den må 'krediteres' ødelæggelsen af den traditionelle by, og hvor den moralske og æstetiske fordømmelse tager form af en afvisning af modernismens elitisme på det formelle såvel som på det sociale plan: Især af adskillelsen af den store ny, utopisk-høj-modernistiske bygning fra dens omgivende bysammenhæng, og den deraf følgende forvandling af høj-modernistiske konstruktioner til så og så mange skulpturer, som Robert Venturi siger det. Post-modernismen vil da tilbyde en slags æstetisk populisme, sådan som titlen på Venturi's manifest, Learning from Las Vegas antyder. Og denne populistiske reto- 
rik antyder, hvordan vi end ønsker at vurdere den, endnu et betydningsfuldt træk ved alle de forskellige postmodernismer i dag, nemlig udviskningen af de gamle grænser mellem finkultur og massekultur, og opkomsten af en ny slags tekster, fyldt med former, kategorier og substanser fra hele det landskab af reklamer og moteller, fra midnatsforstilingen og billigbogs-bestselleren, - med andre ord fra selve den kulturindustri, som blev så lidenskabeligt forkastet af en ældre modernisme.

I det følgende må jeg tage et sådant historisk brud for givet, eftersom jeg vil være mere interesseret $i$ (hvis man ellers er villig til i det mindste hypotetisk at tage det for givet) at beskrive nogle af de mest signifikante træk ved de postmodernismer, som er dette bruds konsekvenser. Men jeg vil gerne på forhånd understrege et andet punkt, og det er, at debatten omkring post-modernismen er langt fra blot at være en rent kulturel eller æstetisk affære. Den involverer for det første en bestemt historisk periodisering, og uundgåeligt vil sådan en periodisering i det rent kulturelle område ikke falde til ro i sig selv, men må lede videre til formodninger om dens tilsvar på det sociale livs andre niveauer. Hvad der i virkeligheden sker er, at antagelsen om en post-modernisme i kulturen meget hurtigt slår over i en hypotese om et helt nyt socialt moment, eller ovenikøbet en helt ny type samfund, hvis mest prominente navn er det "postindustrielle" samfund (Daniel Bell), men som også ofte kaldes forbrugersamfundet, mediesamfundet, informationssamfundet og lignende. Sådanne teorier har næsten altid haft den ideologiske mission at demonstrere, at den nye sociale formation ikke længere adlyder den klassiske kapitalismes love, især den industrielle produktions primat og klassekampens allestedsnærværelse. Disse teorier er derfor for det meste blevet afvist af marxister, med undtagelse af økonomen Ernest Mandel, hvis vigtige bog Late Capitalism, (Senkapitalismen, Oslo/Kbh. 1976) som jeg skal sige mere om senere, påtager sig ikke blot at analysere det nye samfunds historiske originalitet, men også at vise, at det, om noget, er et renere stadium af kapitalismen end de momenter, som gik forud for det. Jeg har ikke tid til her at vise, hvilket ellers kunne dokumenteres righoldigt, at enhver forholden sig til post-modernismen i kulturen - hvadenten den tager form af hyldest eller moralsk modvilje - også i sidste ende er en politisk holdning til den multinationale kapitalismes natur i dag.

Lad os først se på et af høj-modernismens kanoniske værker inden for billedkunsten, Van Gogh's velkendte maleri af bondeskoene, et eksempel der, som man kan tænke sig, ikke er uskyldigt eller tilfældigt 
valgt. Jeg vil foreslå to måder at læse dette maleri på, som begge på en måde rekonstruerer receptionen af værket i en to-stadie- eller dobbeltniveau-proces.

Først vil jeg gerne minde om, at hvis dette mangfoldigt reproducerede billede ikke skal synke ned på det rene dekorations niveau, så kræver det at vi rekonstruerer en eller anden initial situation, som det færdige værk er opstået af. Med mindre den situation - som er forsvundet $\mathrm{i}$ fortiden - på en eller anden måde følelsesmæssigt bliver rekonstrueret, vil maleriet forblive et uvirksomt objekt, et tingsliggjort slutprodukt og være umuligt at forstå som en symbolsk handling i sin egen ret, som praksis og som produktion.

Dette sidste begreb antyder, at én måde at rekonstruere den initiale situation på, som værket på en eller anden måde er et svar på, er at understrege råmaterialerne, den oprindelige substans, som værket stiller sig op imod og som det bearbejder, transformerer og tilnærmer sig. Hos Van Gogh, vil jeg hævde, må dette indhold, disse oprindelige råmaterialer simpelthen forstås som den agrare elendigheds hele objektverden, dens nøgne landlige fattigdom og dens hele rudimentære menneskelige verden af rygbrækkende bondeslid, en verden reduceret til sit mest brutale og truede, primitive og marginaliserede stade.

Frugttræer er i denne verden ældgamle og udpinte stokke, som rager op af den dårlige jord; landsbymenneskene er slidt ned til sokkerne, karikaturer af en grotesk typologi over basale fysiognomiske typer. Hvoraf kommer det da, at ting som æbletræer hos Van Gogh eksploderer ud $i$ en hallucinatorisk flade af farver, mens hans landsby-stereotyper pludseligt og grelt overtrækkes med toninger af rødt og grønt?

Jeg vil kort, i dette første fortolkende bud, hævde, at den villede og voldsomme transformation af en ensformig bonde-objektverden over i den mest gloriøse materialisation af den rene farve inden for oliemaleriet, må ses som en utopisk gestus: Som en kompensationsakt, der munder ud i en helt ny utopisk virkelighed for sanserne, eller i det mindste for den højeste sans - synet, det visuelle, øjet - som den nu rekonstruerer for os som et halv-autonomt rum i sig selv - en del af en ny arbejdsdeling i kapitalens krop, en slags ny fragmentering af det opdukkende sensorium, der genspiller det kapitalistiske livs specialiseringer og delinger, samtidig med at det $\mathrm{i}$ præcis en sådan fragmentering søger en desperat utopisk kompensation for'dem.

Der er, sandt nok, en anden læsning af Van Gogh, som næppe kan ignoreres, når vi ser på dette bestemte maleri, og det er Heideggers centrale analyse i Der Ursprung des Kunstwerkes, som er opbygget omkring ideen om, at kunstværket opstår inden for svælget mellem Jord 
og Verden, eller som jeg ville foretrække at oversætte det: Mellem kroppens og naturens betydningsfattige materialitet på den ene side og historiens og det sociales meningsskabelse på den anden. Vi vender tilbage til dette særlige svælg eller snit senere; lad det være nok her at minde om nogle af de berømte sætninger, som skildrer den proces, hvorved disse for fremtiden illustrere bondesko langsomt omkring sig genskaber hele den manglende objektverden, der engang var deres levede sammenhæng. "I dem, « siger Heidegger, "vibrerer jordens tavse kalden, dens stille gave af modnende korn og dens gådefulde selvfornægtelse $\mathrm{i}$ den vinterlige marks gulbrune trøstesløshed.« "Dette udstyr, « fortsætter han, »tilhører jorden, og det bliver beskyttet i bondekonens verden... Van Gogh's maleri er en åbenbarelse af, hvad udstyret, bondeskoene, i sandhed er... Denne helhed kommer til syne $i$ afsløringen af dens væren, « $i$ kraft af kunstværkets mediation, der drager hele den ikke-tilstedeværende jord og verden ind $i$ en åbenbaring omkring sig, bondekonens tunge gang, markstiens ensomhed, hytten i lysningen, de slidte og brudte arbejdsredskaber i plovfurerne og ved essen.

Heideggers udredning må kompletteres med en insisteren på værkets fornyede materialitet, på dets transformation af én form for materialitet - jorden selv og dens stier og fysiske objekter - over i oliemaleriets anden materialitet, bekræftet og sat i forgrunden for sin egen skyld og sin egen visuelle fornøjelse; men udredningen har ikke desto mindre en tilfredstillende rimelighed over sig.

I hvert fald, begge disse læsninger må beskrives som hermeneutiske, i den forstand at værket i sin stumme, objektmæssige form tages som nøgle til eller symptom på en mægtigere virkelighed, som indtager dets plads som dets endelige sandhed. Nu må vi til at se på sko af en anden slags, og det er rart at kunne finde et sådant billede hos den centrale figur i nutidig visuel kunst. Andy Warhol's »Diamond Dust Shoes « taler helt klart ikke længere til os med den umiddelbarhed, der hæfter ved Van Gogh's fodtøj, ja, jeg er fristet til at sige, at billedet egentlig slet ikke taler til os. Intet i dette maleri organiserer bare et minimalt sted for beskueren, som møder det på hjørnet af en museums- eller gallerigang med et uforklarligt naturobjekts hele tilfældighed. På det indholdsmæssige niveau har vi at gøre med hvad der nu meget klarere er feticher, både i Freuds og Marx' forstand (man vil huske Derrida's bemærkning om det Heidegger'ske bondesko-par, at Van Gogh's fodtøj er et heterosexuelt par, som hverken tillader perversion eller fetichisme).

Her har vi imidlertid en tilfældig samling af døde objekter, som på lærredet hænger akkurat som så og så mange roer, ligeså afskåret fra 
deres tidligere livsverden som skobjergene efterladt i Auschwitz eller som stumperne og mærkerne efter en eller anden uforståelig og tragisk ildebrand i en pakket dansesal. Der er derfor hos Warhol ingen mulighed for at fuldende den hermeneutiske bevægelse og rekonstruere dansesalens eller ballets hele større, levede sammenhæng, jetsetmodeverdenens eller modemagasinernes. Dette er endnu mere paradoksalt i lyset af vor biografiske viden, eftersom Warhol netop begyndte sin kunstneriske karriere som reklame-illustrator for skomode og som designer af udstillingsvinduer, hvor forskellige pumps og slippers var fremtrædende. Faktisk er man fristet til her - alt for tidligt at rejse et af de centrale spørgsmål vedrørende post-modernismen som helhed og dens mulige politiske dimensioner: Andy Warhol's arbejder kredser helt omkring varegørelsen, og de store reklametavlebilleder af Coca-Cola-flasken eller Campbell-suppedåsen, som explicit sætter varefetichismen i overgangen til sen-kapitalismen i forgrunden, burde være magtfulde og kritiske politiske udsagn. Hvis de ikke er det, så ville man gerne vide hvorfor, og man ville begynde at tænke lidt mere seriøst over mulighederne for en politisk eller kritisk kunst $i$ sen-kapitalismens post-moderne periode overhovedet.

Men der er andre betydningsfulde forskelle mellem høj-modernismens og post-modernismens momenter, mellem Van Gogh's og Warhol's sko, som vi nu meget kort må dvæle ved. Den første og mest tydelige er opkomsten af en ny art fladhed eller mangel på dybde, en ny slags overfladiskhed i den mest bogstavelige forstand, - måske det mest fremtrædende formelle træk ved alle de post-modernismer vi vil få lejlighed til at vende tilbage til i en række andre sammenhænge.

For vi må givet tage højde for fotografiets og det fotografiske negativs rolle i nutidig kunst af denne art: Det er præcis det, som skænker sin dødlignende kvalitet til Warhol-billedet, hvis glaserede røntgenstråleelegance krænker betragterens tingsliggjorte øje på en måde, som ikke synes overhovedet at have at gøre med døden eller med dødsbesættelse eller dødsangst på indholdsniveauet. Det er virkelig, som om vi her havde at gøre med omvendingen af Van Gogh's utopiske gestus: I det tidligere værk bliver en hjemsøgt verden ved en eller anden Nietzsche'sk tros- og viljesakt transformeret ind i den utopiske farves skær. Her er det omvendt, som om den ydre og farverige tingenes overflade $-i$ forvejen degraderet og opslugt af sin omformning til blanke reklamebilleder - er blevet revet bort for at afsløre det fotografiske negativs dødlignende sort-hvide underlag, der opretholder den. Skønt denne fremtrædelsesverdens død tematiseres i visse af Warhols billeder - især trafikulykkerne og den elektriske stol-serien så er det ikke, tror jeg, et spørgsmål om indhold længere, men om en 
mere fundamental ændring i objektverdenen selv - som nu er blevet til et sæt tekster eller simulacra - og i subjektets holdning.

Hvilket altsammen bringer mit til det tredje træk jeg gerne vil udvikle kort, nemlig hvad jeg vil kalde folelsens bortsvinden i den postmoderne kultur. Selvfølgelig ville det være upræcist at antyde, at al affekt, al følelse eller emotion, al subjektivitet er forsvundet fra det nyere billede. Der er virkelig tale om en art det fortrængtes genkomst i »Diamond Dust Shoes«, en mærkelig kompensatorisk, dekorativ munterhed, eksplicit udpeget af titlen selv. Det er naturligvis glansen af guldstøvet, det gyldne sands glitren, som forsegler maleriets overflade og dog alligevel fortsætter med at glimte til os. Tænk engang på Rimbaud's magiske blomster "som ser tilbage på dig«, eller på de ærefrygtindgydende, varslende øjelyn fra Rilke's antikke græske torso, der formaner det borgerlige subjekt om at ændre sit liv, helt: Intet af den slags her, i denne dekorative overlejrings vilkårlige frivolitet.

Følelsens bortsvinden kommer man måske iøvrigt i første omgang bedst til rette med via den menneskelige skikkelse, og det er klart, at hvad vi har sagt om varegørelsen af objekterne lige så fuldt gælder for Warhol's menneskelige subjekter, stjerner, der selv er varegjort og forvandlet til deres eget billede. Og også her tilbyder en vis hårdhændet tilbagevenden til høj-modernismens ældre periode en dramatisk tilspidset parabel over den omstridte forvandling. Edvard Munch's maleri »Skriget« er jo naturligvis et kanonisk udtryk for de store modernistiske temaer om fremmedgørelse, anomi, ensomhed, social fragmentering og isolation, et rent ud programmatisk emblem for det der engang plejede at blive kaldt angstens tidsalder. Jeg ønsker meget for kort her - at se det som legemliggørelsen ikke bare af udtrykket for denne slags affekter, men især som en faktisk dekonstruktion af selve udtrykkets hele rstetik, som synes mig at have domineret meget af det vi kalder høj-modernismen, men også at være blevet udslettet - af både praktiske og teoretiske grunde - i den postmoderne verden. Selve udtrykkets idé forudsætter i virkeligheden en vis adskillelse inden for subjektet, og med den en hel metafysik om indre og ydre, om den omverdensløse smerte inde i monaden, og om det øjeblik, hvor denne 'følelse', ofte katarsisk, så bliver projiceret og eksternaliseret i det ydre, som gestus eller skrig, som desperat kommunikation og ydre dramatisering af en indre følelse. Og det er måske så nu tidspunktet til at sige noget om nutidig teori, som bl.a. har været forpligtet på den opgave at kritisere og miskreditere selve den hermeneutiske model om indre og ydre og at stigmatisere sådanne modeller som ideologiske og metafysiske.

Men hvad der i dag kaldes nutidig teori - eller bedre, teoretisk 
diskurs - er altså, vil jeg gerne argumentere for, selv helt præcist et post-moderne fænomen. Det ville være inkonsistent at forsvare sandheden af sådanne teoretiske indsigter $i$ en situation, hvor selve begrebet 'sandhed' er en del af den metafysiske bagage, som post-strukturalismen søger at afskaffe. Hvad vi i det mindste kan antyde er, at den post-strukturalistiske kritik af hermeneutikken, af det jeg kort vil kalde dybde-modellen, er nyttig for os som et meget vigtigt symptom på selve den post-moderne kultur, som er vores emne her.

Hastigt kan vi sige, at ved siden af den hermeneutiske model om indre og ydre, som Munchs billede udvikler, er der mindst fire andre fundamentale dybdemodeller, som generelt er blevet afvist af den nutidige teori: Den dialektiske mellem væren og fremtrædelse (sammen med en hel række begreber om ideologi og falsk bevidsthed, som plejer at ledsage den); den freudianske model om latent og manifest, eller om regression (som naturligvis er skydeskiven for Michel Foucault's programmatiske og ekstremt symptomatiske pamflet Viljen til viden); for det tredje den eksistentialistiske model om autenticitet og inautenticitet, hvis heroiske eller tragiske tematik er nært knyttet til den anden store modsætning, mellem fremmedgørelse og ikke-fremmedgørelse, selv lige så fuldt et offer for den post-strukturalistiske eller post-moderne periode; og til slut, sidst i tid, den store semiotiske modsætning mellem udtryk (signifiant) og indhold (signifié), som meget hurtigt blev dekonstrueret og trævlet op i løbet af sin korte karriere i 1960'erne og -70'erne.

Hvad der træder i stedet for disse forskellige dybdemodeller er overvejende en forestilling om praksis'er, diskurser og et tekstligt spil, som vi har mere at sige om senere: Lad det være nok her at bemærke, at også her er dybde afløst af overflade, eller af mangfoldige overflader (hvad der ofte kaldes intertekstualitet er i den forstand ikke længere et spørgsmål om dybde overhovedet).

Ej heller er denne dybdeløshed blot metaforisk: Den kan opleves fysisk og bogstaveligt af enhver, der kører op ad hvad der engang var Raymond Chandler's Beacon Hill i Los Angeles og pludselig møder Crocker Bank-centrets fritstående mur, en overflade som synes at være designet til at blive set to-dimensionalt. Hvilken slags volumen støtter denne uhyre overflade? Det er umuligt at sige om den formodede bygnings rum er rektangulært, triangulært eller af anden art. Der er uden tvivl et oplivende sus i betragtningen af denne store fritstående flade af vinduer, som synes at udfordre vores normale oplevelse af masse, ligesom den store monolit i Kubricks 2001, som møder den præ-udviklingsmæssige menneskelighed som en gådefuld skæbne, som en opfordring til evolutionær mutation. På den anden 
side, og vi vil komme tilbage til dette spørgsmål til slut, kan der ikke være tvivl om, at sådanne ejendommelige arkitektoniske former forrykker vores traditionelle begreber om og erfaring af byen på en foruroligende måde og forvandler byen til noget meget problematisk for vores konventionelle evne til at fatte og repræsentere.

Vender vi nu kort tilbage til Munch, kunne man ønske at vise hvor omhyggeligt maleriet dekonstruerer sin egen udtryksæstetik, samtidig med at det forbliver indelukket af dens fundamentale grænser. Maleriets gestiske indhold understreger allerede dets egen kommen til kort, eftersom lydens verden, skriget, den menneskelige strubes rå vibrationer, per definition er uforenelige med den visuelle repræsentations stumme medium, noget der inden for værket er understreget af hovedpersonens manglende oren.

Dog genindsætter dette skrigets fravær fra maleriets stilhed blot atter dialektikken mellem indre og ydre, projicerer os længere ind i det svimle dyk, som fører fra det fraværende skrig til den endnu mere fraværende virkelighed af oprørende ensomhed og angst, som skriget selv skulle 'udtrykke'. Sådanne dyk optræder igen på den malede overflade i form af de store koncentriske cirkler, hvori lydbølgerne bliver synlige, som på en vandoverflade, og som endelig som en vifte spredes ud fra den lidende og bliver selve hans univers' materielle geografi, en smerte der er blevet denne solnedgangs og dette landskabs inderste substans.

Nu må vi haste videre: Jeg vil hermed antyde, - og i denne form må antydningen forblive kategorisk og dogmatisk - at begreber som angst og fremmedgørelse ikke længere svarer til den post-moderne tid. De store Warhol-skikkelser, Marilyn Monroe eller Edie Sedgewick - celebre eksempler på udbrændthed og selvdestruktion i slutningen af 1960'erne og på de fremherskende erfaringer med drugs og skizofreni - har ikke meget til fælles mere hverken med hysterikerne og neurotikerne fra Freuds æra eller med de oplevelser af radikal isolation og ensomhed, af anomi, privat revolte eller Van Gogh-agtig galskab, som dominerede høj-modernismens periode. På en yderst skematisk måde kan dette skift i den kulturelle patologis dynamik ses som en proces, hvorigennem subjektets fremmedgørelse fortrænges af dets fragmentering.

Sådanne termer genkalder uvægerlig en af de mere fashionable strømninger i nutidig teori - den om selve subjektets 'død', individets og den autonome borgerlige monades endeligt - og betoningen, enten som en ny moralsk værdi eller som en empirisk beskrivelse, af decentreringen af det tidligere centrerede subjekt. Men problemet omkring udtrykket er klart nok også meget tæt knyttet til den ældre forestilling 
om subjektet som en monadeagtig beholder, hvori ting føles, som så bliver udtrykt gennem en udadgående projektion. Og skønt vi ikke har gjort denne anden forbindelse eksplicit synes det klart, at højmodernismens forestilling om en unik stil (sammen med den kollektive høj-modernistiske idé om den kunstneriske avantgarde) også må stå og falde med den ældre forestilling (eller erfaring) om det såkaldt centrerede subjekt.

Også her står Munchs billede som en kompleks refleksion over denne komplicerede situation: Det viser os, at udtrykket kræver den individuelle monades kategori, men det viser også den høje pris, der må betales for denne forudsætning, idet det dramatiserer det ulykkelige paradoks, at når man konstituerer sin individuelle subjektivitet som et selvtilstrækkeligt felt og en lukket virkelighed i sig selv, så lukker man sig derved ude fra alt andet og fordømmer sig selv til monadens vindstille ensomhed, levende begravet og dømt til en fængselscelle uden udgang.

Post-modernismen vil formentlig betyde afslutningen på dette dilemma, som den erstatter med et nyt. Afskeden med det borgerlige jeg eller monaden betyder uden tvivl også afskeden med dette jegs psykopatologi - hvad jeg her alment har kaldt følelsens bortsvinden. Men det betyder afskeden med meget mere, - afskeden med f.eks. stil, i betydningen det unikke og personlige, afskeden med det karakteristiske, individuelle penselstrøg (som det symboliseres af forkærligheden for mekanisk reproduktion). Med hensyn til udtryk og folelser eller emotioner, kan befrielsen i dagens samfund fra det centrerede subjekts tidligere anomi også betyde, ikke blot en befrielse fra angst, men også befrielse fra enhver slags følelse, eftersom der ikke længere er noget selv til stede til at have følelsen. Det vil ikke sige, at den postmoderne æras kulturelle produkter er ganske drænet for følelse, men snarere at sådanne fólelser - som det måske er bedre og mere præcist at kalde 'intensiteter' - nu er fritflydende og upersonlige og tenderer mod at være domineret af en mærkelig eufori, som jeg vil komme tilbage til til slut.

Følelsens bortsvinden kunne imidlertid også i den litterære kritiks snævrere sammenhæng karakteriseres som en bortsvinden af de store høj-modernistiske tematikker tid og tidslighed, de elegiske mysterier ved la durée og erindringen (noget der må forstås fuldt så meget som en kategori i den litterære kritik knyttet til høj-modernismen som i værkerne selv). Vi har imidlertid så tit fået at vide, at vi nu bebor det synkrone snarere end det diakrone, og jeg tror at det i det mindste er empirisk rimeligt at sige, at vores dagligliv, vores psykiske erfaring, vores kulturelle sprog, i dag domineres af rum-kategorier snarere end 
af tids-kategorier som i den foregående, egentlig højmodernistiske periode.

Jeg kan ikke udvikle dette videre langt her, men må i det mindste $\mathrm{i}$ forbifarten understrege forbindelsen mellem den stigende rumliggørelse, eller $\mathrm{i}$ hvert fald af-temporalisering, og så et andet fundamentalt karakteristikum $\mathrm{i}$ vores kultur og samfund som iagttagere har instisteret på. Man taler om historicitetens gradvise formørkelse, tabet af enhver vital sans for fortiden i al dens radikale forskellighed fra os, og den tilsvarende manglende evne til at danne sig billeder af eller projektere radikalt forskellige fremtider - en manglende evne, der som man vel kan forestille sig, har øjeblikkelige såvel politiske som æstetiske konsekvenser. Hvis vi havde tid ville jeg gerne have vist denne proces i funktion i massekulturen, i hvad der er kommet til at hedde nostalgi-film (eller la mode rétro) og på et andet niveau af den kulturelle produktion i E.L. Doctorow's Ragtime, som bedre end nogen anden nutidig roman dramatiserer fortidens forvandling under post-modernismen til rene billeder og stereotyper af denne fortid, forskydningen af fortiden fra at være referent til en ny oplevelse af fortiden som simulacrum og som pseudo-fortid.

En sådan nostalgi-kunst er organiseret efter pastichens kategori og svarer til det som arkitektur-historikere kalder 'historicisme', nemlig den vilkårlige kannibalisering af alle fortidens stilarter, spillet med vilkårlige stilistiske allusioner og $\mathrm{i}$ almindelighed med hvad Henri Lefebvre kalder den stigende forrang for begrebet 'neo'. Noget som ikke udelukker en vis humor, som arkitektur-kritikerne minder os om, og som heller ikke er uforeneligt med lidenskab eller i det mindste med forfaldenhed - med en hel, historisk original forbrugerappetit på en verden forvandlet til lutter billeder eller simulacra (den identiske kopi, for hvilken ingen original nogensinde har eksisteret) af sig selv, på pseudo-begivenheder og skuespil, i et samfund hvor bytteværdien er generaliseret til en grad, hvor selve erindringen om brugsværdien er blevet udslettet, et samfund hvori, som Guy Debord i en sigende frase har bemærket det, »billedet er blevet den endelige form for vare-tingsliggørelsen.«

Men denne beskrivelse kræver nu, at vi på en ny måde vender tilbage til spørgsmålet, om ikke om tiden selv eller tidsligheden, så dog i det mindste om den tidsmæssige organisation. For hvis subjektet har mistet sin identitet, dvs. sin evne til at fastholde tiden og at organisere sin fortid og fremtid i en sammenhængende erfaring, så er det svært at se hvordan et sådant subjekts kulturelle produkter skulle blive andet end »en bunke fragmenter « og en praksis af det vilkårligt heterogene, fragmentariske og tilfældige. Dette er imidlertid stadig 
negative eller blot private forklaringer på post-modernistisk form: Dens positive formuleringer bærer navne som tekstualitet, écriture eller skizofren skrift, og det er disse vi nu kort må behandle.

Jeg har fundet Lacans teori om skizofreni brugbar her, ikke fordi jeg har nogen chance for at vide om den er klinisk præcis eller nyttig mere som suggestiv æstetisk model, med andre ord som beskrivelse snarere end som diagnose. I virkeligheden er jeg meget langt fra at mene, at nogen af de mest betydningsfulde postmodernistiske kunstnere - Cage, Ashbury, Sollers, Robert Wilson, Ishmael Reed, Michael Snow, Warhol eller endog Beckett selv - er skizofrene i klinisk forstand. Ejheller er pointen nogen kultur- og personlighedsanalyse af vores samfund og dets art som i psykologiserende og moraliserende kulturkritikker af typen Christopher Lasch's Narcissismens kultur, som jeg gerne radikalt vil distancere nærværende bemærkningers ånd og metodologi fra: Der er, skulle man synes, langt mere krasse ting at sige om vort sociale system end kan hentes fra pop-psykologien.

Meget kort sagt beskriver Lacan skizofreni som et sammenbrud i udtrykskæden, dvs. den indbyrdes sammenhængende syntagmatiske serie af udtryk, som konstituerer en ytring eller en betydning. Jeg må her udelade den vanlige eller mere ortodokse psykoanalytiske baggrund for denne situation, som Lacan 'oversætter' til sprog ved at beskrive Ødipus-rivaliteten i forhold til ikke så meget det biologiske individ, det som er ens rival til moderens opmærksomhed, men snarere til hvad han kalder Faderens Navn, den faderlige autoritet, som nu anskues som en lingvistisk funktion. Hans forestilling om udtrykskæden forudsætter essentielt et af de basale principper (og en af de store opdagelser) i Saussure'sk strukturalisme, nemlig sætningen om, at betydning ikke er et ét-til-ét forhold mellem udtryk og indhold, mellem sprogets materialitet, et ord eller et navn, og så dets referent eller begreb.

Betydning skabes efter dette synspunkt gennem bevægelsen fra udtryk til udtryk: Hvad vi almindeligvis kalder indhold - betydningen eller det begrebsmæssige indhold af en ytring - skal snarere ses som en betydnings-effekt, som tegngivningens objektive illusion, skabt og projiceret af forholdet mellem udtrykkene indbyrdes. Når dette indbyrdes forhold bryder sammen, når leddene i udtrykskæden knækker, så har vi skizofreni i form af brokker af adskilte og usammenhængende udtryk. Sammenhængen mellem denne form for lingvistisk malfunktion og den skizofrenes psyke kan da begribes ved hjælp af en dobbelt sætning: For det første, at personlig identitet i sig selv er effekten af en vis tidslig forening af fortid og fremtid med den nutid der foreligger for én; og for det andet, at en sådan aktiv tidslig 
forening i sig selv er en funktion af sproget, eller bedre endnu, af sætningen, som den bevæger sig igennem sin hermeneutiske cirkel i tiden.

Hvis vi ikke er $\mathrm{i}$ stand til at forene sætningens fortid, nutid og fremtid, så er vi tilsvarende ude af stand til at forene fortid, nutid og fremtid i vores egen biografiske erfaring eller psykiske liv. Med udtrykskædens sammenbrud er den skizofrene derfor reduceret til en oplevelse af rent materielle udtryk, eller med andre ord af en serie usammenhængende nu'er i tid. Vi vil om et øjeblik stille spørgsmål til de æstetiske og kulturelle resultater af en sådan situation; lad os forst se hvordan den føles:

"Jeg husker meget tydeligt den dag det skete. Vi var på landet, og jeg var gået en tur alene som jeg gjorde det engang imellem. Pludselig, da jeg kom forbi skolen, hørte jeg en tysk sang; børnene havde sangtime. Jeg stoppede for at lytte, og i det øjeblik kom der en mærkelig følelse over mig, en følelse det er svært at analysere, men som lignede noget, som jeg skulle komme til at kende alt for godt senere hen, - en skræmmende følelse af uvirkelighed. Det var som om jeg ikke længere kunne genkende skolen, den var blevet stor som en kaserne; de syngende børn var fanger, tvunget til at synge. Det var som om skolen og børnenes sang var blevet skilt fra resten af verden. Samtidig mødte mit øje en hvedemark, hvis grænser jeg ikke kunne se. Den gule uendelighed, blændende i solen, forbandt sig med børnenes sang, som de var spærret inde i den glatte stenskolekaserne, og fyldte mig med sådan en angst, at jeg brød i hulkende gråd. Jeg løb hjem til vores have og begyndte at lege »for at få tingene til at være som de plejede, «dvs. for at komme tilbage til virkeligheden. Det var den første tilsynekomst af de elementer, som altid var til stede i de senere oplevelser af uvirkelighed; ubegrænset uendelighed, strålende lys og de materielle tings skinnen og glathed.«

(Marguerite Séchehaye: Autobiography of a Schizophrenic Girl, N.Y. 1968, p. 19)

I'vores nuværende sammenhæng giver denne oplevelse anledning til følgende bemærkninger: Først løsriver sammenbruddet af tidsligheden abrupt nutidssituationen fra alle de aktiviteter og formålsmæssigheder, der kunne have fokuseret den og gjort den til et praksis-rum; således isoleret opsluger nutidssituationen så pludselig subjektet med 
en ubeskrivelig livagtighed, en perceptionsmæssig materialitet, der er rent ud overvældende, og som effektivt dramatiserer udtrykkets materielle, eller bedre, bogstavelige magt, når det isoleres. Dette den materielle udtryksverdens nu kommer til subjektet med forhøjet intensitet og indebærer en mystisk affektiv ladning, som her er beskrevet i negative termer som angst og virkelighedstab, men som man lige så godt kunne forestille sig fremstillet i positive termer som eufori, at være høj, den berusede eller hallucinerede intensitet.

Hvad der foregår $\mathrm{i}$ tekstualiteten eller den skizofrene kunst bliver slående belyst af sådanne kliniske beretninger, skønt det isolerede udtryk i den kulturelle tekst ikke længere er en gådefuld verdenstilstand eller et uforståeligt, skønt hypnotiserende sprogfragment, men snarere noget der ligger tæt på sætningen i fritstående isolation. Tænk f,ex. på oplevelsen af John Cage's musik, hvor en sværm af materielle lyde (på det præparerede klaver f.eks.) følges op af en stilhed så utålelig, at man ikke kan forestille sig at nogen næste klangfuld akkord overhovedet kan komme til verden, og hvor man i hvert fald ikke kan forestille sig at man kan huske den foregående godt nok til at knytte nogen forbindelse til den næste, hvis den alligevel kommer. Nogle af Beckett's fortællinger er også af denne art, vel navnlig Watt, hvor den aktuelle sætnings forrang i tid skånselsløst disintegrerer det narrative netværk, der forsøger at gendanne sig omkring den.

Mit eksempel er imidlertid mindre dystert, en tekst af en yngre San Fransiscodigter, hvis gruppe - den såkaldte Language Poetry eller New Sentence-skole - synes at have tilegnet sig skizofren fragmentering som deres fundamentale æstetik.

»Kina«

Vi lever på den tredje verden fra solen. Nummer tre. Ingen fortæller os hvad vi skal gøre.

Dem, der lærte os at tælle, var meget venlige.

Det er altid tid at bryde op.

Hvis det regner har du enten en paraply eller ikke.

Vinden blæser din hat af.

Solen står osse op. 
Jeg ville helst ha' stjernerne ikke beskrev os for hinanden; jeg ville hellere vi gjorde det selv.

Løb foran din skygge.

En søster, der peger mod himlen mindst en gang pr. tiår, er en god søster.

Landskabet er motoriseret.

Toget forer dig hen hvor det skal.

Broer blandt vande.

Folk strejfer i spredte grupper henover enorme betonflader, på vej til flyet.

Glem ikke hvordan din hat og dine sko vil se ud, når du ikke kan findes nogetsteds.

Selv de ord der flyder i luften danner blå skygger.

Hvis det smager godt, spiser vi det.

Bladene falder. Peg ting ud.

Saml de rigtige ting op.

Hej, ved du hvad? Hvad? Jeg har lert at tale. Stærkt.

Den person, hvis hoved var ufuldendt, brød $\mathbf{i}$ gråd.

Da den faldt, hvad kunne dukken så gøre? Ingenting.

Sov nu.

Du ser flot ud i shorts. Og flaget ser osse flot ud.

Alle ku' li' eksplosionerne.

Det er tid at vågne. 
Men væn dig hellere til drømme.

(Bob Perelman)

Meget kunne siges om denne interessante øvelse i diskontinuiteter: Genkomsten af en mere forenet global betydning henover disse adsplittede sætninger er ikke den mindst paradoksale. Faktisk synes det, forsåvidt som det på en mærkelig og hemmelighedsfuld måde er et politisk digt, at indfange noget af ophidselsen over det umådelige, ufuldendte sociale eksperiment i det nye Kina - uden sidestykke i verdenshistorien - den uventede tilsynekomst, mellem de to supermagter, af "nummer tre«, friskheden $i$ en helt ny objekt-verden, produceret af mennesker med en ny kontrol over deres kollektive skæbne, og fremfor alt: En kollektivitet, der er blevet et nyt »historiens subjekt«, og som efter den lange undertrykkelse under feudalisme og imperialisme igen taler med sin egen stemme, for sig selv, som for første gang (»Hej, ved du hvad? Jeg har lært at tale!«).

Jeg har imidlertid især villet vise den måde, hvorpå hvad jeg har kaldt skizofren disjunktion eller ecriture, når den bliver generaliseret til kulturel stil, ophører med at have et nødvendigt forhold til det morbide indhold vi associerer med ord som skizofreni, og derved bliver tilgængelig for mere muntre intensiteter, for præcis den eufori, som vi så erstatte de ældre følelser af angst og fremmedgørelse.

Sammenlign f.eks. Jean-Paul Sartre's redegørelse for en lignende tendens hos Flaubert:

"Hans sætning omringer objektet, griber det, gør det tavst, brækker ryggen på det, svøber sig om det, forvandler sig til sten og forstener sit objekt sammen med sig. Den er blind og døv, blodløs, uden et pust af liv; en dyb stilhed skiller den fra den sætning, der følger efter; den falder i afgrunden, for evigt, og trækker sit bytte med ned i det uendelige fald. Enhver virkelighed, som engang blev beskrevet, bliver strøget af inventarlisten«.

(fra Hvad er litteratur?)

Det er en værdifuld, skønt fjendtlig anatomisk skildring af hvad man kunne kalde de post-modernistiske eller skizofrene rørelser hos en vis Flaubert (der er mange andre). Men klart nok synes det ikke synderligt egnet som karakteristik af ånden i Perelman's digt.

Det sidstnævnte har imidlertid en anden kompositorisk hemmelighed ved sig, som vi nu må afsløre. I virkeligheden er det repræsente- 
rede objekt i Perelman's digt slet ikke Kina. Forfatteren har fortalt, hvordan han, mens han gik rundt $i$ Chinatown, $i$ en bod faldt over en bog med interessante fotografier, en bog hvis kinesiske overskrifter og tekster selvfølgelig forblev døde ord for ham (eller skulle man sige materielle udtryk?). Sætningerne i digtet er Perelmans undertekster til disse billeder, deres referenter er andre billeder, en anden fraværende tekst; og digtets enhed er slet ikke i dets tekst, men uden for det, $i$ en anden, fraværende bogs indbundne enhed. Bedraget er ikke uligt det, der findes $\mathrm{i}$ fotorealismen, som lignede en tilbagevenden til repræsentationen efter den abstrakte ekspressionismes og dens æstetiks lange hegemoni, indtil folk begyndte at finde ud af, at det nyere maleri slet ikke kunne siges at være realistisk $\mathrm{i}$ nogen traditionel forstand, eftersom dets referent ikke var nogen virkelig eller ydre verden, men snarere blotte fotografier af denne verden, eller med andre ord, denne sidstnæunte i forvejen transformeret til billeder - for hvilke det fotorealistiske maleri nu bliver simulacrum.

Denne redegørelse for skizofreni og tidslig organisering kunne imidlertid også være formuleret på en anden måde, som ville bringe os tilbage til Heideggers idé om svælget eller bruddet, omend på en måde der ville have forfærdet ham. I virkeligheden vil jeg gerne karakterisere den post-modernistiske erfaring med formen ved noget, som vil synes, håber jeg, et paradoksalt slogan: Nemlig den sætning, at »forskellen forbinder." Vor egen aktuelle kritik fra Macherey og videre frem har været interesseret $i$ at understrege kunstværkets heterogenitet og dybe diskontinuiteter, et værk er ikke længere forenet eller organisk, men en veritabel gramsepose eller et pulterkammer af usammenhængende sub-systemer, vilkårlige råmaterialer og impulser af enhver art. Det tidligere kunstværk har nu med andre ord vist sig at være en tekst, hvis læsning skrider frem via differentiering snarere end via sammensmeltning. Teorierne om differens har imidlertid haft en tendens til at understrege sammenhængsløsheden til det punkt, hvor tekstens materialer inklusive dens ord og sætninger er tilbøjelige til at falde fra hinanden i vilkårlig og træg passivitet, i et sæt elementer som har rent ydre adskillelser fra hinanden.

I de mest interessante post-modernistiske værker kan man imidlertid iagttage en mere positiv opfattelse af forbindelse, som genopretter dens behørige spænding til ideen om differensen selv. Denne nye fremtrædelsesform for forbindelse gennem differens kan sommetider være en nyopnået og original måde at tænke og opfatte på; oftere tager den form af et umuligt imperativ om at opnå denne nye mutation i hvad der måske ikke længere kan kaldes bevidstheden. Jeg tror, at det mest slående udtryk for denne nye måde at tænke relationer 
kan findes i Nam June Paik's arbejder, hvor stablede eller spredte TV-skærme, placeret med intervaller midt i en yppig vegetation, eller blinkende ned til os fra et loft af sære nye video-stjerner, igen og igen gentager præ-arrangerede sekvenser eller sløjfer af billeder, som vender tilbage på usynkroniserede tidspunkter på de forskellige skærme.

Den ældre æstetik praktiseres så af de tilskuere, som forvirret af denne diskontinuerte forskellighed, beslutter sig til at koncentrere sig om en enkelt skærm, som om den relativt værdiløse billedsekvens som man der kan følge, havde en eller anden organisk værdi i sig selv. Den post-modernistiske tilskuer bliver imidlertid bedt om at gøre det umulige, nemlig at se alle skærmene på én gang, i deres radikale og vilkårlige forskellighed. En sådan tilskuer indbydes til at følge den evolutionsmæssige mutation hos David Bowie i Manden, som kom ned på jorden, og på en eller anden måde hæve sig til et niveau, hvor den livagtige perception af radikal forskel i og af sig selv er en ny måde at gribe det, som plejede at hedde forbindelse: Noget, for hvilket ordet collage stadig kun er et meget mat navn.

Vi må nu afrunde denne forklarende redegørelse for post-modernistisk rum og tid med en afsluttende analyse af den eufori eller de intensiteter, som så ofte synes at karakterisere den nyere kulturelle erfaring. Lad os atter understrege den enorme forvandling, der lader bygningerne hos en Edward Hopper eller den nøgne Midtvest-syntaks i Sheelers former bag sig, og erstatter dem med det fotorealistiske 'byskab's mærkværdige overflader, hvor selv bilvragene stråler med en ny hallucinatorisk pragt. Den løftede stemning ved disse nye overflader er så meget mere paradoksal, eftersom deres væsentlige indhold - byen selv - er sunket sammen eller disintegreret i en grad, som helt sikkert var utænkelig $i$ begyndelsen af det 20 . århundrede, for slet ikke at tale om den forudgående periode.

Hvordan bymæssig elendighed kan blive en nydelse for øjet, når den udtrykkes i varegørelse, og hvordan et kvalitativt spring uden sidestykke $i$ fremmedgørelsen af dagliglivet $i$ byen nu kan opleves $i$ form af en mærkelig ny hallucinatorisk munterhed - det er nogen af de spørgsmål vi står overfor her mod slutningen af vores undersøgelse. Ej heller bør den menneskelige skikkelse udelukkes fra undersøgelse, selvom det synes klart, at for den nyere astetik er fremstillingen af rummet selv blevet noget, der føles uforeneligt med fremstillingen af kroppen: En slags æstetisk arbejdsdeling langt mere end i nogen af de tidligere, fælles opfattelser af landskabet, og et yderst ildevarslende symptom ovenikøbet.

Det privilegerede rum i den nyere kunst er radikalt anti-antropomorft. som i de tomme badeværelser i Doug Bond's arbejder. Den 
yderste aktuelle fetichering af den menneskelige krop tager imidlertid en meget anderledes retning i Duane Hanson's statuer - det jeg allerede har kaldt simulacrum, hvis særlige funktion ligger $i$, hvad Sartre ville have kaldt de-realisationen af dagligdagsvirkelighedens hele omverden. Éns tøven og tvivl med hensyn til disse polyesterfigurers åndedræt og varme tenderer med andre ord mod at vende sig imod de virkelige mennesker, der bevæger sig rundt i museet, og mod i et kort øjeblik at forvandle dem til så og så mange døde og kødfarvede simulacra selv. Verden mister dermed momentant sin dybde og truer med at blive en skinnende hud uden tæthed. Men er dette nu en skræmmende eller en opløftende oplevelse?

Det har vist sig frugtbart at tænke over sådanne oplevelser ud fra det, Susan Sontag engang i et indflydelsesrigt udsagn udskilte som camp. Jeg vil fremkalde en noget andet belysning af det, idet jeg trækker på det lige så fashionable aktuelle tema, det 'sublime', som det er blevet genopdaget i Edmund Burke's værker og hos Kant; eller måske skulle man ligefrem prøve at forene de to ideer $\mathrm{i}$ form af noget $\mathrm{i}$ retning af det camp-eller "hysterisk « sublime. Det sublime var som man vil huske for Burke en oplevelse grænsende til rædsel, - det stødvise glimt, i forbavselse, lammelse og ærefrygt, af noget som var så enormt, at det kunne knuse menneskelivet helt og holdent: En beskrivelse som siden blev forfinet af Kant til også at omfatte spørgsmålet om selve den æstetiske fremstilling - således at det sublimes genstand ikke blot er et spørgsmål om ren magt og om den fysiske usammenlignelighed mellem den menneskelige organisme og naturen, men også et spørgsmål om grænserne for gestaltning overhovedet og om den meneskelige bevidstheds afmagt med hensyn til at fremstille så enorme kræfter.

Sådanne kræfter var Burke, i sit historiske øjeblik ved den moderne borgerlige stats daggry, kun i stand til at begrebsliggøre som det guddommelige; mens endnu Heidegger fortsætter med at reflektere over en fantasmatisk forbindelse til et eller andet prækapitalistisk bondelandskab og landsbysamfund, hvilket er slutformen for billedet af Naturen i vor egen tid.

I dag er det dog måske muligt at tænke alt dette på en anden måde, her i øjeblikket for selve Naturens radikale formørkelse: Heideggers "marksti« er năr alt kommer til alt uhjælpeligt og uigenkaldeligt ødelagt af senkapitalismen, af den grønne revolution, af neo-kolonialismen og af mastodont-byen, som trækker sine super-motorveje hen over de tidligere marker og de ledige jordlodder, og gør Heideggers "værens-hus« til ejerlejligheder, hvis"ikke til de mest jammerlige uopvarmede, rottebefængte lejekaserner. Det andet i vores samfund er 
i den forstand slet ikke længere Naturen, som det var det i prækapitalistiske samfund, men noget anderledes, som vi nu må identificere.

Det er mig magtpåliggende, at dette andet ikke forhastet identificeres som teknologien i og for sig, eftersom jeg gerne vil vise, at teknologien her selv er en figur for noget anderledes. Dog kan teknologien godt gøre fyldest som adækvat billede til at angive den enorme, egentligt menneskelige og antinaturlige kraft af dødt menneskeligt arbejde, som er oplagret i vort maskineri, en fremmedgjort magt, som Sartre kalder praksis-træghedens kontrafinalitet, der vender os ryggen og vender sig imod os $i$ uigenkendelige former og synes at udgøre den massive dystopiske horisont for såvel vor kollektive som vor individuelle praksis.

Teknologien er imidlertid ud fra et marxistisk synspunkt resultatet af kapitalens udvikling snarere end nogen første årsag i sig selv. Det vil derfor være rimeligt at skelne mellem flere generationer af maskinkraft, flere stadier i den teknologiske udvikling inden for kapitalen selv. Jeg følger her økonomen Ernest Mandel, der i sin bog Senkapitalismen opridser tre sådanne fundamentale brud eller kvalitative spring i den maskinelle udvikling under kapitalismen:

»De fundamentale revolutioner inden for kraft-teknologien det vil sige teknologien i produktionen af drivmaskiner ved hjælp af maskiner - viser sig således at være det afgørende element i de teknologiske revolutioner som helhed. Maskinproduktion af dampdrevne motorer siden 1848; maskinproduktion af elektro- og forbrændingsmotorer siden 1890-erne; maskinproduktion af elektroniske og atomdrevne apparaturer siden 1940erne - det er de tre hovedrevolutioner inden for teknologien, skabt af den kapitalistiske produktionsmåde siden den 'oprindelige' industrielle revolution i det sene 18. århundrede.«.

Denne periodisering understreger den generelle tese i Mandel's bog, nemlig at der har været tre fundamentale faser i kapitalismen, som hver markerer en dialektisk udvidelse af det foregående stadium: det er markedskapitalismen, monopolstadiet eller imperialismens stadium, og vor egen fase - forkert kaldt den post-industrielle - som snarere burde benævnes den multinationale kapitals stadium. Jeg har allerede påpeget, at Mandels intervention over for det post-industrielle bygger på den antagelse, at sen- eller multinational- eller forbrugerkapitalismen langt fra at være uforenelig med Marx' store 19.århundrede-analyse tværtimod udgør den reneste form for kapital 
der hidtil er opstået, en formidabel udvidelse for kapitalen ind $\mathrm{i}$ hidtil ikke-varegjorte områder.

Denne renere kapitalisme i vor egen tid eliminerer således de enklaver af præ-kapitalistisk organisering den hidtil havde tolereret og kun udbyttet på begrænset måde. Man er fristet til i denne forbindelse at tale om en helt ny og historisk original gennemtrængning og kolonisering af naturen og det ubevidste - det vil sige ødelæggelsen af den præ-kapitalistiske tredje verdens landbrug gennem den grønne revolution og opkomsten af medierne og reklameindustrien. I hvert fald vil det også være fremgået, at min egen kulturelle periodisering af stadierne realisme, modernisme og post-modernisme både er inspireret af og bekræftes af Mandels tredelte skema.

Vi kunne derfor tale om vor egen tid som den tredje (eller måske allerede fjerde) maskin-alder; og det er her vi igen må rejse problemet vedrørende den æstetiske fremstilling, som det allerede eksplicit er udviklet i Kants analyse af det sublime - eftersom det kun ville forekomme logisk, at forholdet til og gestaltningen af maskinen måtte forventes at skifte dialektisk for hvert af disse kvalitativt forskellige stadier af den teknologiske udvikling.

Det er derfor rimeligt at genkalde sig maskinbegejstringen i den foregående kapitalistiske fase, den loftede stemning især i futurismen og i Marinettis hyldest til maskingeværet og bilen. Disse er stadig synlige emblemer, energiens skulpturelle knudepunkter, som giver håndgribelighed og form til drivenergierne i den pågældende fase af moderniseringen. Disse store strømlinede formers prestige kan måles på deres metaforiske tilstedeværelse i Le Corbusier's bygninger, umådelige utopiske strukturer der 'sejler' som så og så mange gigantiske dampskibslinere henover en ældre, falden jords urbane sceneri.

Maskineriet udøver en anden fascination på kunstnere som Picabia og Duchamp, som vi ikke har tid til at beskæftige os med her; men lad mig, for fuldkommenhedens skyld, nævne den måde revolutionære eller kommunistiske kunstnere i 1930'erne også søgte at gentilegne sig maskinbegejstringen på, $i$ en prometeisk rekonstruktion af det menneskelige samfund som helhed, som hos Fernand Leger og Diego Rivera.

Hvad der da straks bør bemærkes er, at vor egen tids teknologi ikke længere på samme måde lader sig gestalte æstetisk: Det er ikke turbinen, ej heller Sheelers kornelevatorer eller fabriksskorstene, ikke den barokke udfletning af rør og transportbånd, heller ikke jernbanetogets strømlinede profil - altsammen fartmaskiner, der stadig står koncentreret, selv $\mathrm{i}$ hvile - nej, det er snarere computeren, hvis ydre skal ingen emblematisk eller visuel kraft har, eller endda selve de 
hylstre de forskellige medier er indkapslet i som det er tilfældet med det hjemmeapparat der kaldes fjernsyn, som intet artikulerer, men snarere vender sig indad og bærer sin fladtrykte billedoverflade inden i sig selv.

Sådanne maskiner er reproduktions- snarere end produktionsmaskiner, og de stiller meget anderledes krav til vore evner til æstetisk fremstilling end den relativt mimetiske tilbedelse af det ældre maskineri i futurismen, $i$ en eller anden ældre fart-og-energi skulptur, gjorde det. Her har vi i mindre grad at gøre med bevægelsesenergi end med alle mulige former for nye reproduktionsprocesser; og i de svagere post-modernistiske produkter tenderer den æstetiske legemliggørelse af sådanne processer ofte til at falde komfortabelt tilbage i en blot tematisk fremstilling af indhold - i fortællinger, der handler om reproduktions-processerne, og som inkluderer filmkameraer, video, båndoptagere, hele den produktions- og reproduktionsteknologi, der knytter sig til et simulacrum. Når japanske arkitekter f.eks. former en bygning i dekorativ imitation af stabler af båndkassetter, så er løsningen $\mathrm{i}$ bedste fald tematisk og alluderende, omend ofte humoristisk.

Noget andet er dog ved at dukke op i de mest energiske postmodernistiske tekster, og det er fornemmelsen af, at hinsides alt tematisk og indholdsmæssigt synes værket på en eller anden måde at tappe reproduktionsprocessens netværker og derved at tilbyde os et kig ind i det post-moderne eller det teknologisk sublime, hvis kraft eller autenticitet dokumenteres gennem værkernes evne til at fremmane et helt nyt post-moderne rum, der er under dannelse omkring os. Arkitekturen forbliver således det privilegerede æstetiske sprog; og forvrængnings- og fragmenterings-spejlingerne af én enorm glasoverflade i en anden kan ses som paradigmatisk for den centrale rolle, proces og reproduktion spiller i den post-modernistiske kultur.

Jeg vil imidlertid ikke påstå, at teknologien på nogen måde skulle være den "sidste bestemmende instans«, hverken for vor aktuelle sociale liv eller vor kulturelle produktion: En sådan påstand ville selvfølgelig stemme overens med den post-marxistiske idé om et "post-industrielt« samfund. Snarere vil jeg antyde, at vore mangelfulde fremstillinger af et umådeligt kommunikations- og computernetværk blot er et fordrejet billede af noget dybereliggende,nemlighele nutidens multinationale kapitalistiske verdenssystem. Det moderne samfunds teknologi er derfor hypnotiserende og fascinerende, ikke så meget i sig selv, men fordi den synes at frembyde en art privilegeret og koncentreret billede, der kan gribe et netværk af magt og kontrol, som er endnu vanskeligere at fatte for vor tanke og indbildningskraft - nemlig hele det nye, decentrerede globale netværk i kapitalens tredje stadium. Det er derfor efter min mening alene ud fra denne 
uhyrlige og truende og dog kun vagt opfattelige anden virkelighed, at det post-moderne sublime kan teoretiseres og forståes fyldestgørende.

Jeg skal til slut søge kort at fremmane de mest interessante konsekvenser af min analyse af post-modernismen, og især de problemer som har at gøre med det mulige politiske indhold i den nyere kunst. Vi er nødt til at postulere, tror jeg, en slags gennemgribende modifikation eller mutation i selve kulturens sfære og funktion i sen- eller multinational-kapitalismen. En sådan mutation kan beskrives som en enorm ekspansion i kulturen til et punkt, hvor dens tidligere autonomi går tabt, og alt i vort sociale liv - fra økonomi og politik til psyken og de tidligere overbygningsstrukturer - er blevet ét med kulturen selv. At sige at alting er blevet en pseudo-begivenhed eller et billede eller et skuespil forudsætter kulturens generelle ekspansion. Men dette forudsætter igen, at kulturen - ikke længere autonom eller halvautonom som område - er ved at miste sin evne til kritisk distance, til negativitet, til undergravning og $i$ almindelighed til politisk indgriben, hvordan man så end opfatter en sådan. Det var i alt væsentligt det problem jeg forsøgte at reje tidligere $\mathrm{i}$ forbindelse med det politiske indhold i Andy Warhols kunst.

Men problemet drejer sig lige så meget om vore kritiske og teoretiske kategorier som om værkerne: Tesen om en restrukturering af dagens samfund og et skift i kulturens tidligere funktion har som forudsætning, at vore vante opfattelser af politisk kultur eller kulturpolitik - som stort set er baseret på modeller for selvbevidsthed, for negation og undergravning, for kritisk distance - ikke længere er brugbare i den aktuelle situation.

Jeg vil derfor meget forsøgsvis foreslå en anden kulturel model, som markerer en vis tilbagevenden til de kognitive og pædagogiske modeller for politisk kunst som kan findes i meget forskellig form både hos Lukács og hos Brecht. Modsat deres vil min model imidlertid være rumlig og taget det, som i dag ofte kaldes 'kognitiv kortlægning' som sit organiserende princip. I et berømt værk, The Image of the City, har Kevin Lynch gjort opomærksom på, at den fremmedgjorte by er et rum, hvor folk er ude af stand til at kortlægge såvel deres egne positioner som den bymæssige og sociale totalitet de befinder sig $i$. Af-fremmedgørelse ville da indebære en praktisk generobring af stedsansen og opbygningen af en rumlig, men også social verden, hvor det individuelle subjekts forhold til hans eller hendes fællesskab igen bliver gennemsigtigt og fremstilleligt. Man vil derfor i min anvendelse af Lynch mærke inspirationen fra Althussers fremragende definition af ideologi som "fremstillingen af subjektets imaginere forhold til sine virkelige eksistensvilkår:« En definition som jeg her stort set omformulerer $i$ retning af position og sted, og $i$ hvilken det bymæssige rum blot er figur for socialt rum og den sociale totalitet $i$ alminde- 
lighed.

Sandt nok er ingen kritik af post-modernistisk arkitektur og by-liv helt så kraftfuld og foruroligende som den, der kan rettes mod dens ødelæggelse af ældre former for by-rum, noget der synes at forlænge den destruktive indflydelse fra den arkitektoniske høj-modernisme (som på sin side blev gjort til genstand for en korrekt post-modernistisk kritik), men som markerer, tror jeg, en kvalitativ forandring og en dialektisk intensivering af denne. Hvad der sker i nye offentlige rum som hyper-markederne eller Bonaventura-hotellet i Los Angeles er en dobbelt bevægelse i retning af eufori og fremmedgørelse (eller måske skulle jeg sige skizofreniering): På den ene side er man nu underkastet et nyt, totalt miljø, hvor selv de tomme rum på en eller anden måde er fyldt ud, og hvor man lever sin nu postmoderne krop på en ny måde; på samme tid er man helt berøvet orienteringspunkter og er ude af stand til at lokalisere sig selv i forhold til noget som helst: Et træk, der kan illustreres af utilfredsheden hos de handlende i Bonaventura-centret, som beklager sig over, at folk simpelthen ikke kan finde deres butikker og i hvert fald ikke kan finde dem én gang til. Alt dette intensiveres nok engang i nyere post-moderne bykomplekser som La Defense eller de nye byer rundt om Paris. Ikke bare afskaffelsen af gaden som kategori (noget der allerede var godt på vej i den modernistiske periode), men fremfor alt fjernelsen af profiler og endog de perspektiver, dybder, ledningsnet og regelmæssigheder, som tillader én at måle en bygnings placering i forhold til en anden. Det er som om disse forvirrende komplekser endegyldigt har ødelagt rummet i den ældre betydning af et netværk af steder og nu befinder sig hinsides naturen og stofligheden i en ny dynamik af frie former.

Der er ikke tale om at vende tilbage til et ældre maskineri, et ældre og klarere nationalt system eller en mere traditionel og beroligende enklave af perspektivisk rum. Men hvis min analyse er korrekt, så synes $\mathrm{i}$ det mindste en bestemt kulturpolitik eller ny type politisk æstetik at trænge sig på, uden at der er nogen mulighed for at vide, om den kan lykkes eller ej. Det ville være en kunst, som holdt fast $i$ post-modernismens sandhed, dvs. dens fundamentale genstand - den multinationale kapital - og som alligevel brød igennem til en endnu ukendt form for gestaltning, hvor vi igen kunne begynde at fatte vores placering som individer og kollektive subjekter og genvinde en evne til at handle og kæmpe, noget der for nærværende er neutraliseret af vor rumlige og sociale forvirring. Post-modernismens politiske form, hvis den nogensinde făr nogen, vil have sin mission i en fornyelse af den kognitive kortlægning, i social såvel som i en rumlig henseende. 